\title{
Virtual Action Learning: Experiences from a study of an SME e-Learning Programme
}

\author{
Jean-Anne Stewart and Gillian Alexander \\ Henley Management College, UK \\ \{Jean-anne.stewart, Gillian.Alexander\}@henleymc.ac.uk
}

\begin{abstract}
This paper presents the findings from a project investigating management development for SME managers using an action learning programme, combining both face-to-face workshops and a virtual action learning environment. The project aimed to address 3 main objectives: reworking results from previous European projects to disseminate to a wider audience, creating a learning network/ community amongst the project partners and to undertake 3 learning trials with SMEs in UK, France and Italy. This paper principally addresses the findings from the UK trials, which ran between February and April 2005, and provides valuable learning to all those interested in developing future learning programmes aimed at SMEs.
\end{abstract}

Keywords. e-learning, action learning, management, development, programme, SME

\section{Introduction}

\subsection{Why consider Virtual Action Learning for SMEs?}

SMEs (small and medium-sized enterprises) represent $99 \%$ of all businesses in Europe and account for more $50 \%$ of the employment and turnover figures in the UK. Small businesses in the UK (employing less than 50 people) represent $47 \%$ of employment and $37 \%$ of turnover. (Small Business Survey, 2004). However only $24 \%$ of SMEs provide vocational education and training compared to $80 \%$ of large enterprises (employing over 250 people). SMEs play a key role in generating employment and creating economic wealth, but skill deficiencies in SMEs are adversely affecting their ability to reach their growth potential (British chamber of commerce Surey, 2002). By their very nature, SMEs are small, constrained by time and budget and reluctant to engage in learning programmes, therefore the purpose of research projects such as ENSeL is to investigate how SMEs can be engaged in appropriate learning interventions to address this major challenge. Action learning has previously been successfully used with SMEs on earlier projects and this study aims to investigate the effectiveness of virtual action learning to engage SMEs.

\subsection{ENSeL Project Organisation}

The ENSeL project, coordinated by Henley Management College (HMC), aimed to share the learning from five EU funded projects/networks all of which contained a core e-learning element. The projects being integrated included the PeLM project

E. Tomadaki and P. Scott (Eds.): EC-TEL 2006 Workshops, pp. 369-384, 2006. 
(Programmes in learning through e-learning for managers), eLIVE (eLearning and Knowledge Management for European SMEs), ESeN (European SME e-Learning Network), ROCKET (Roadmap to communicating knowledge essential for the industrial environment) and EQUEL (e-quality in elearning, the EQUEL Virtual Centre of Excellence).

The initial project tasks culminated in a review of the learning frameworks emerging from EQUEL and the other represented EU projects. These were then formulated to make them suitable for European SMEs. These principles of learning for SMEs were drawn on prior project experience with SMEs and have been reviewed in light of the results of the ENSeL project. During the review, an approach to the SME trial design emerged that was similar to action learning (Revans, 1980), but also included a virtual environment. Action learning is certainly not a new development in the education of managers. Indeed some of the early approaches to management development (Wilmott, 1994) saw an emphasis on sharing experience and less on content. The Syndicate or 'Set' method was devised for this purpose with the rationale of helping managers to 'help themselves' via practical problem solving around real life issues. Some of the advantages of virtual action learning directly address the needs of SMEs: flexibility, cost benefits, location is not a barrier, freedom to work at own pace, less disruption to work schedules and an opportunity to shape the learning agenda or content.

Based on the characteristics of the target audience for the trial, namely SMEs, ENSeL has elaborated some learning principles to inform the use of sustainable networked learning in SMEs. These principles are grounded in the position papers about e-learning in Higher Education, which are the final output of the EQUEL project, and draw mostly on theories supporting social learning, socio-cultural approach to learning and social constructionism (Hodgson and Watland, 2004).

\subsection{ENSeL Learning Principles}

The following principles informed the design of the SME trials at the beginning of the project. These were later revised in view of the findings, as discussed in the final section of this paper:

1. Our focus is on learning and learner-managed environments.

2. Learning is better supported in collaborative settings and dialogue plays a major part in the collaborative learning process.

3. Social interaction allows for co-construction of knowledge, which promotes engagement of learners in work based and problem-based learning.

4. The role of the facilitator/animator is essential for collaborative e-Learning.

5. Critical reflexivity is an important part of the learning process for evaluating and examining both the learning process itself and the resultant actions taken.

6. Learning is situated and context dependent.

\section{Literature Review}

\subsection{Learning in SMEs}

Specific considerations with regard to learning place certain requirements on any learning programme for SMEs, as summarised in Figure 1 (Alexander, 2006). 


\begin{tabular}{|c|c|}
\hline Considerations & Programme Requirements \\
\hline $\begin{array}{l}\text { Increasing competition and } \\
\text { development of } \\
\text { markets are major concerns for } \\
\text { small businesses (Bolden, 2001). There } \\
\text { is a high } \\
\text { 'churn' of SMEs in the UK (SBS, } \\
\text { 2003a). }\end{array}$ & 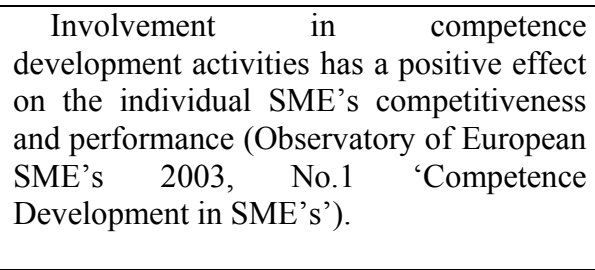 \\
\hline $\begin{array}{l}\text { Formal methods of teaching and } \\
\text { learning are not necessarily the most } \\
\text { appropriate way of engaging, } \\
\text { motivating and transferring knowledge } \\
\text { to today's workforce (Williams, 2003). } \\
\text { Formal training is not the best way of } \\
\text { learning for SMEs (Atwell, 2003). }\end{array}$ & $\begin{array}{l}\text { Non-formal (informal) learning } \\
\text { constitutes the most important way of } \\
\text { acquiring and developing the skills and } \\
\text { competencies required at work (Eraut, } \\
\text { 2000) }\end{array}$ \\
\hline $\begin{array}{l}\text { The primary concern within SME's } \\
\text { is keeping the company running on a } \\
\text { day-today basis (Cranfield, 2005). } \\
\text { Enmeshed in the practicalities of } \\
\text { running their businesses, SME leaders } \\
\text { have lost any interest they may once } \\
\text { have had in theoretical issues (Inglis, } \\
\text { 1994). }\end{array}$ & $\begin{array}{l}\text { Training has to be focused on the } \\
\text { specific needs of the enterprise (Unisys, } \\
\text { 2005). } \\
\text { Active learning focuses on solving real } \\
\text { problems and the learner's experience } \\
\text { 'accounts for as much as the teacher's } \\
\text { knowledge' (Knowles, 1984) }\end{array}$ \\
\hline $\begin{array}{l}\text { The SME leader's own negative } \\
\text { attitude to } \\
\text { change and learning (Observatory of } \\
\text { European SME's 2003, No.1 } \\
\text { 'Competence Development in SME's'). } \\
\text { Time devoted to learning is considered } \\
\text { by many as lost time (Unisys, 2005) }\end{array}$ & $\begin{array}{l}\text { When individuals are involved in the } \\
\text { learning process dealing with issues of } \\
\text { relevance to their careers they become } \\
\text { motivated learners (Bray, 2002). } \\
\text { To get effective motivation the learner } \\
\text { should be put in the centre of learning, 'the } \\
\text { starting point must be a question from the } \\
\text { learner'. (Unisys, 2005) }\end{array}$ \\
\hline $\begin{array}{l}\text { SMEs are driven primarily by profit } \\
\text { (Hilton \& Smith, 2001) SMEs expect } \\
\text { impact on bottom line (Unisys 2005, } \\
\text { LSDA, 2002) }\end{array}$ & $\begin{array}{l}\text { Promotion - no matter how good the } \\
\text { training and support material, It has to be } \\
\text { carefully promoted and delivered to be } \\
\text { effective. It must go to considerable lengths } \\
\text { to highlight the commercial benefits of } \\
\text { business improvement (non - } \\
\text { commercial benefits can be promoted as } \\
\text { secondary benefits once the main } \\
\text { commercial message has got thought). The } \\
\text { aim is to make SMEs actually want to take } \\
\text { part in the initiative and to make them see } \\
\text { management development as integral to } \\
\text { good business practice (Hilton \& Smith, } \\
\text { 2001). }\end{array}$ \\
\hline
\end{tabular}




\begin{tabular}{|c|c|}
\hline $\begin{array}{l}\text { Learning is a cost, and the SME } \\
\text { owner does not always consider it as an } \\
\text { investment for the future (Unisys, } \\
\text { 2005). }\end{array}$ & $\begin{array}{l}\text { The programme should have a } \\
\text { measurable impact within the organisation } \\
\text { and should be affordable and value for } \\
\text { money (Bolden, 2001). }\end{array}$ \\
\hline $\begin{array}{l}\text { SMEs use a short term approach, } \\
\text { they only set up a training action plan } \\
\text { when they face real problems (Unisys, } \\
\text { 2005) Just-in-time (JIT) learning fulfils } \\
\text { SME short term information } \\
\text { needs (Unisys, 2005) }\end{array}$ & $\begin{array}{l}\text { Approaches to learning, training and } \\
\text { development in small firms needs to take } \\
\text { account of the shorter planning time frames } \\
\text { they use by relating learning opportunities } \\
\text { and benefits to these shorter time frames.( } \\
\text { Stanworth et al, 1992). }\end{array}$ \\
\hline Time pressures (Bolden, 2001) & $\begin{array}{l}\text { SMEs like courses to be flexible and } \\
\text { modular so that they can dip in and out, } \\
\text { taking 'bite-sized' pieces (a few hours at a } \\
\text { times) as they see fit and as their workload } \\
\text { permits (Unisys, 2005). Due to time } \\
\text { pressures close locality of programmes is } \\
\text { also important (LSDA, 2002; Kirby, 1990) }\end{array}$ \\
\hline $\begin{array}{l}\text { eLearning is beginning to have an } \\
\text { impact on } \\
\text { learners, and particularly those } \\
\text { demanding } \\
\text { flexibility, accessibility and } \\
\text { connectivity (Bisoux, 2002) Growing } \\
\text { pressure in many industrial societies to } \\
\text { identify the most constructive and cost } \\
\text { effective ways of using ICT as a } \\
\text { resource for learning (Guile, 1998). }\end{array}$ & $\begin{array}{l}\text { Some of the advantages of e-learning } \\
\text { directly address the needs of SME's: } \\
\text { flexibility, cost benefits, location is not a } \\
\text { barrier, freedom to work at own pace, less } \\
\text { disruption to work schedules. (Unisys, } \\
\text { 2005) }\end{array}$ \\
\hline $\begin{array}{l}\text { Much of the knowledge developed, } \\
\text { often by the owner/ manager, remains } \\
\text { tacit and unshared. } \\
\text { The new kinds of knowledge are } \\
\text { 'tacit' and } \\
\text { 'developmental', and are practical as } \\
\text { opposed to being theoretical as they are } \\
\text { derived from action and experience. } \\
\text { (Williams, 2003) }\end{array}$ & $\begin{array}{l}\text { Communities of practice could support } \\
\text { inter-firm collaboration (Van Winklen, } \\
\text { 2003). Learning can be better supported in } \\
\text { settings of collaboration, where they } \\
\text { interact with each other and learn from } \\
\text { each other (Esnault \& Ponti, 2004) }\end{array}$ \\
\hline $\begin{array}{l}\text { Learning has increasingly become } \\
\text { seen as } \\
\text { dependent on the activity of the } \\
\text { learner (Knowles, 1984, Williams, } \\
\text { 2003). SMEs are generally action } \\
\text { orientated and learn by doing (Kirby, } \\
199\end{array}$ & $\begin{array}{l}\text { The Action learning method requires } \\
\text { that the problems to be solved are real } \\
\text { ones. They are not manufactured for the } \\
\text { learning situation. Action learning is a } \\
\text { method for individual and organisational } \\
\text { development... people tackle important } \\
\text { issues or problems and learn from their } \\
\text { attempts to change things (Pedler, Brook \& } \\
\text { Burgoyne, 2003). }\end{array}$ \\
\hline
\end{tabular}


Isolation of the enterprise owner is a barrier to learning. Learning is a social activity (Esnault \& Ponti, 2004)
An informal environment should be built to aid networking. The network should provide a forum for exploring ideas with peers, and give support to individuals (Birchall et al, 2004). Network learning broadens access and participation of SMEs in real-life learning environments (Ponti, 2004) Network technology offers the opportunity to facilitate, strengthen and connect SMEs in order to build and enhance networks of business at the regional, national, or international level (Esnault \& Ponti, 2004)

Figure 1: Considerations to SME learning and programme requirements

\subsection{Action Learning}

Taking into account recent theories on situated learning and the programme requirements outlined in Figure 2, a learning approach based on Revans' work on action learning (Revans, 1980) is likely to be the most appropriate for SME owner/managers. "Action learning is a method for individual and organisational development. Working in small groups, people tackle important issues or problems and learn from their attempts to change things" (Pedler, Brook and Burgoyne, 2003). There are four elements:

1. Each person joins in and takes part voluntarily.

2. Each participant must own a managerial or organisational problem on which they want to act.

3. Sets or groups of action learners meet to help each other think through the issues and create options.

4. They take action and learn from the effects of that action (Pedler et al., 2003).

There are a number of requirements for action learning: the set, the project, the set adviser, set meetings, and workshops.

\subsection{E-learning in SMEs}

Although action learning addresses many of the requirements of learning programmes for SMEs, it may be that a combination of e-learning and action learning may be even better. Some of the advantages of e-learning directly address the needs of SMEs: flexibility, cost benefits, location is not a barrier, freedom to work at own pace, less disruption to work schedules. However, there are some disadvantages, such as selfdiscipline, loneliness, and dealing with large quantities of electronic materials. When adapting an action learning programme to e-learning, Bray (2002) warns that the pedagogic baggage that both tutors and associates carry is clearly a barrier that needs to be overcome, as is developing different interpersonal tools of communication and style. Ingram et al. (2000) also warn that care must be taken with both hard (hardware, software, administration, financial support) and soft (human relationships, communication, goodwill) critical success factors. This has implications for the set members, set meetings and workshops, resources, and the set adviser. 


\subsection{Networked Management Learning}

Hodgson and Watland (2004) defined networked management learning as learning that is supported by ICT used to connect learners with other people (learners, tutors, mentors, etc.) and to learning resources and information of various kinds. Network technology offers the opportunity, through the use of computer-mediated communication and/or via the internet, to catalyze, strengthen and connect SMEs in order to build and enhance networks of business at the regional, national, or international level. Among the other aims, technology holds the potential to connect individuals/groups/organizations to resources they need for their work activities; to create a sense of community where people can share knowledge but preserve diversity; to organize events that bring business and other institutional actors to support a collaborative and cooperative approach to learning. The ENSEL project can be most closely defined as a trial in networked management learning.

\section{Methodology}

\subsection{The Research Design}

The design of the research can be considered as a case study or three individual case studies, if dealing with one trial at a time. This was an empirical investigation aimed at understanding the different ways in which SME managers described their experience of networked management learning. The purpose of the study was not testing hypotheses but exploring what participants thought and felt about their participation in the trials by asking questions that led them to relate their experiences and explore their attitudes to networked management learning. Qualitative data was collected using registration forms, one-to-one interviews, focus groups and facilitated face-to-face workshops, in addition to questionnaires. Quantitative data was collected using participant questionnaires, completed at the beginning and the end of the trial.

\subsection{Participants}

The trial included a total of 56 SMEs in UK, France and Italy. The 29 UK trial participants included healthcare professionals, financial services managers, IT and telecom consultants, manufacturing and engineering company owners and managers, recycling business managers, providers of educational services, music publishers, website developers and suppliers of social and leisure services.

\subsection{The Trial Design}

The trial was designed as a blend of face-to-face and online activities, coordinated by facilitators, as shown in the ENSeL Roadmap (Figure 2). The trial design aimed at moving away from traditional pedagogical and didactical approaches by allowing participants to learn through the group process. Throughout the trial, the participants were encouraged to keep track of their learning and to develop their capacity for reflection.

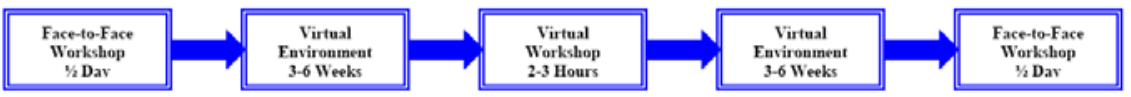

Figure 2: Roadmap of the SME trial design 
The virtual action learning was facilitated throughout the programme, with one facilitator allocated to each learning set of between 5 and 8 participants. The learning sets worked through a schedule of activities agreed at the first workshop, with each product being reviewed by the set members at weekly intervals. The groups decided on the nature of the products and these were typically short documents or presentations, which evolved to summarise their challenges and actions (An example is shown in Appendix A). These virtual reviews consisted of questions being posed and stories and experiences shared to support each participant with their specific business issues. The facilitator was available to provide additional resources as requested by the group and entered the virtual discussion area at least every 48 hours.

\subsection{The Initial Workshop}

The first workshop was successful in many ways. The groups worked well together and there was very positive feedback on the action learning approach. The groups identified their challenges and started in different ways to agree their approach to the interim working using the virtual learning platform. The time spent on coffee breaks and lunch involved much sharing of experiences between the group members, generally described as 'feeling that they were not alone with their problems - there were others in the same boat'. Informally they offered help and suggestions to each other.

However, there were some aspects of the workshop that did not go as well as expected. For many, there was a lot covered in one morning, and the pace was too fast. Secondly the technology was not available for the training session and the short demonstration given was not sufficient to give the participants any confidence in being able to use the virtual learning platform after the workshop. Finally the participants were not all comfortable with the vague nature of the proposed tasks. This was particularly evident amongst the more traditional industry groups, who really wanted clear tasks, explicit delivered course content and a precise structure to their learning programme. This was least evident amongst the group of entrepreneurs, who quickly grasped the idea of defining tasks, allocating work amongst the group members and appointing one group member as co-ordinator.

\subsection{Virtual Learning}

Following the initial workshop, the groups were registered for the discussion forum and expected to continue their group activities on-line. However there were significant technical problems that meant that this could not happen. Different groups resolved these technical problems, in different ways. One group decided to abandon the discussion forum within the first week and communicated entirely by email. This group had also appointed a co-ordinator and went on to collaborate very successfully. Another group moved onto a very structured tool based approach where they worked individually on a one-to-one basis with the facilitator. The other groups persevered longer with trying to use the discussion forum, but unsuccessfully. This led to a complete lack of collaboration between the group members. Thiswas one of the reasons that caused the interim workshop in the UK to be changed to allow a face-toface session, as well as on-line presentations. Email communication was continued 
throughout the trial, but as discussed, only one group worked collaboratively and the other groups worked on individual tasks as guided by their facilitator.

\subsection{The Interim Workshop}

The primary deliverable was intended to be a presentation of the group's activities and results from the first half of the trial and these presentations were to be reviewed by the other groups. All the presentations were published in the discussion forum and sent by email. A small group of UK participants met face-to-face for an afternoon and the presentations were reviewed constructively during the session. The French SMEs adopted 'Skype' for their interim workshop to supplement the discussion forum. The groups also raised the issue of needing more structure to the learning programme, and this resulted in the UK group generating (in the face-to-face session) a diagnostic tool, which they then worked through on a step-by-step week-by-week basis. They also decided to include their individual learning reflections with the weekly summaries.

\subsection{The Final Workshop}

This event was scheduled as a morning and lunch session, as discussed earlier. The groups' task was to present their summaries of challenges, activities and action plans to each other and then summarise to the other groups in the plenary session. They spent almost the whole morning working in their learning sets, with only about one hour in large group presentation and discussion. The groups spent a significant amount of this time considering their reflections on the programme and their learning.

\section{Summary of Results}

\subsection{SME Perspectives of the Trial}

The participants recorded their experiences in groups and individually on the posttrial questionnaires. Analysis of the questionnaires resulted in $73 \%$ stating that they had met at least some of their objectives, and $67 \%$ stating that they would be able to apply their learning in their personal and professional life within 12 months. There were $90 \%$ of participants who agreed that it had been useful to share with others and $77 \%$ felt that they had become more effective managers. It was interesting to note that whilst there was a poor response to questions about the on-line collaboration area, $73 \%$ of participants found the help of the facilitators very useful. Some of the SME comments are summarised below:

\begin{tabular}{|l|l|}
\hline & SME Comments \\
\hline What was successful? & $\begin{array}{l}\text { Very enjoyable and useful face-to-face sessions - } \\
\text { encouraged virtual collaboration } \\
\text { Encouraged further thinking on management issues } \\
\text { Personal (one-to-one) discussions over drinks / lunch } \\
\text { Structured tools and templates very helpful, especially the } \\
\text { Challenge Diagnostic }\end{array}$ \\
\hline
\end{tabular}




\begin{tabular}{|c|c|}
\hline & $\begin{array}{l}\text { Facilitators helped to push it along during the virtual learning } \\
\text { phase } \\
\text { Access to facilitators and group members by email } \\
\text { Face-to-face sessions preferred, maybe due to 'age' of } \\
\text { participants (felt virtual learning may be more easily adopted } \\
\text { by younger people) } \\
\text { Collaborative aspect was great } \\
\text { Learning from others was very worthwhile } \\
\text { Realising shared issues (it can be lonely as an SME) } \\
\text { Generation of insights } \\
\text { Access to resources (e-Library) was valuable } \\
\text { Really helped to reality check the business and re-focus on } \\
\text { the basics and essential of business } \\
\text { Realised that interpersonal development was more important } \\
\text { than academic learning }\end{array}$ \\
\hline $\begin{array}{l}\text { What was NOT so } \\
\text { successful? }\end{array}$ & $\begin{array}{l}\text { Technology was very slow and not intuitive } \\
\text { Lack of collaboration following face-to-face sessions } \\
\text { Wanted more structure and direct content (some) in the } \\
\text { programme } \\
\text { Disappointed in the lack of commitment of other members of } \\
\text { the group } \\
\text { Difficult to schedule time for remote learning and give up if } \\
\text { it doesn't work easily or quickly }\end{array}$ \\
\hline $\begin{array}{l}\text { Recommendations for } \\
\text { Future }\end{array}$ & $\begin{array}{l}\text { Clearer structure at the beginning and more tasks with } \\
\text { deadlines } \\
\text { More face-to-face sessions } \\
\text { More time spent bonding as a team, rather than group } \\
\text { Get the right virtual learning platform (fast, intuitive, simple) }\end{array}$ \\
\hline
\end{tabular}

\subsection{Facilitators' Perspectives}

Following the trial, the facilitators held a small workshop to review the trial and produced the following reflections. In view of the comments from the SMEs, identical comments are not reiterated here, and only additional comments and observations are included. The trial facilitators agreed the following:

- The initial workshop and marketing information should have contained more detailed information on the structure and expectations of a virtual action learning programme

- Successful virtual collaboration was also supported by informal communication such as telephone conversations, one-to-one emails and meetings in pubs etc.

- The scheduling of face-to-face events at about every 4 to 5 weeks was about right to maintain interest in the virtual action learning

In summary, the facilitators considered that there are constant opposing challenges to running such programmes, such as structure, timing, numbers of participants, and technology. The participants expect clear objectives, tasks and outcomes to varying degrees depending on their preferred personality type and learning style. Some want a lot of detail, and others will require only high-level information. Too much detail can be restrictive and too little creates uncertainty. The group size of between 4 and 8 
people is good for action learning sets, whereas a larger number, over 30 is better to create lively virtual discussions. It was essential to build trust between the participants themselves, as well as in the programme providers.

\section{Conclusions and Implications for Further research}

The overall conclusion of this study is that it is possible to successfully engage SMEs by using an engagement strategy that communicates in terms of meeting by SME needs and addressing their current business problems. The combination of face-toface and virtual action learning worked well on this project, and helped to encourage the SMEs to join the programme. The need for a clear structure to the programme was underestimated and in the future more attention should be given to informing potential participants of the structure, tasks and the expectations of their involvement.

The facilitation of the trial was successful in many aspects, however, possibly due to the technical issues; this role took significantly more time and effort than expected. There was a need for facilitators to be in communication almost on a daily basis and use a flexible style to motivate the participants. There were times when a 'light touch' of facilitation was sufficient and also times when the participants looked for clear directions and guidance. In light of these experiences and following a careful reflection of the findings, the ENSEL project partners revised the initial 6 learning principles to the following 8:

1. Our focus is on learning which has a perceived value to the learners

2. Responsibility for the learning process is shared (between all actors in this process)

3. Learning is situated and context-dependent

4. Time has to be allowed to build relationships

5. Learning is better supported in collaborative settings and dialogue plays a major part in the collaborative learning process

6. Social interaction allows for co-construction of knowledge, which promotes engagement of learners in workbased or problem-based learning

7. The role of the facilitator / animator is essential for collaborative learning

8. Critical reflexivity is an important part of the learning process for evaluating and examining both the learning process itself and the resultant actions taken.

\subsection{Implications}

This study raised several interesting points for further research. Firstly, there was a tendency by both participants and facilitators to blame many of the problems with virtual learning on the technology problems. It would be valuable to investigate how much this masked other issues about using a virtual action learning approach. Some of the participants expressed the view that their lack of collaboration and motivation in using virtual learning was down to their age (average in 40s) and stated that a younger generation brought up with the internet and web-based learning at schools and colleges would be more accepting of virtual learning environments. The findings of these trials indicate the possible model, below: 


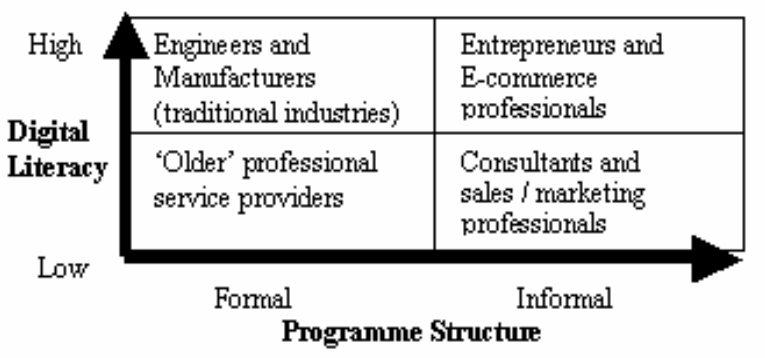

Figure 3: Structure / Digital Literacy Matrix (Stewart and Alexander, 2006)

The above model attempts to illustrate that those with a higher digital literacy and greater acceptance of the more informal problem-based action learning tended to come from businesses of entrepreneurs, with innovative new products and services, often exploiting new technology. Many of these were providing complex information technology products and offering unique web-based services.

Those with a higher digital literacy that preferred the more traditional formal type of programme, tended to be from the more traditional industries and were often initially educated in engineering and science based disciplines. For many of these, this was their first experience of an action learning programme. Whilst the majority of the participants realised benefits at the end of the programme, they tended to be very suspicious of a programme with a facilitator, rather than a teacher.

The participants with lower digital literacy were very reluctant to use technology. The requirements for participants attending the ENSEL programme had been stated as they needed to be able to use email and access the internet. There was one example of a participant who met these criteria, but his first email was written in the style of a very formal business letter. This indicated challenges in the attitude towards the technology, not just the technical skills of sending emails.

Those that were reluctant to use technology preferred both formal and informal structures. Some, who referred to themselves as an 'older' generation, stated that they had come from a tradition of formal, structured education at school and college, where you were taught to read books, learn facts and listen to the teacher. This group reflected that a younger generation brought up to question and challenge, research on the Internet, complete online examinations, and use technology for study and leisure, would have more easily accepted virtual action learning.

The group of people with low digital literacy but a preference for informal learning emphasised their satisfaction at the face-to-face events and appreciated the opportunity to discuss quite loosely-defined problems with the others in the group. Comments were made concerning trust, especially when there was the potential that the other members of the group might be competitors. This was particularly evident in the Italian trial, which resulted in a reluctance to collaborate and share knowledge, apart from at face-to-face events. This category of participants was particularly emphatic on the need to spend time getting to know the people in the group first. The above model indicates the challenges in engaging SMEs for virtual action learning programmes and the need to provide programmes that either encompass all 
approaches or, alternatively, are targeted at a particular group. For those that fall into the category of lower digital literacy, this would need to be addressed, prior to engaging them in action learning programmes supported with technology.

The type of challenges the SMEs worked on in this programme often involved revealing aspects of their businesses and personal effectiveness that they were comfortable to talk about in face-to-face meetings but were reluctant to submit to online discussion forums. There needs to be a more in-depth investigation on to how to facilitate trust, collaboration and open communication in a virtual learning environment. The constant tension between the business pressures on SMEs to be totally dedicated to their companies and the benefits of taking time out for learning and reflection should be investigated further, to attempt to identify ways to allow the participants to develop trust and simultaneously does not involve them spending several days away from their business.

Overall, this project has made some interesting findings and provides valuable insights into developing effective virtual action learning programmes for SMEs.

The digital literacy matrix above provides an indication of how action learning sets might be set up to reflect both the differing needs for structure and the variation in digital literacy. This trial has indicated that virtual action learning was most effective in the low structure/high literacy quadrant. Those in the low structure/low literacy quadrant could benefit from either traditional face-to-face action learning programmes or alternatively, they could start the programme with a well-designed, succinct training programme to help develop their digital literacy skills. The facilitator for such a group would also need to be able to address and resolve technical queries and therefore should possess technical competencies, in addition to facilitation competencies.

Those that are in the high structure quadrants could be allocated into action learning sets containing similar participants and the set facilitator should pay particular attention to ensure that there are people in the set with specific knowledge and expertise to encourage rich action learning experiences in the group. Once the group appreciate the action learning process, this group would then be able to move to virtual action learning. This implies that it would take longer and more face-to-face meetings would be needed before this group could move onto virtual action learning. Those that are in the formal structure and low digital literacy quadrant would also need to spend additional time on a training programme to help develop their technical skills. Therefore this group would be the least appropriate group to engage on a virtual action learning programme.

This research project was designed to investigate the potential benefits of virtual action learning to engage SMEs in learning programmes, in order to address the major challenge of developing skills in SME owners and managers. The learning principles originally drawn for prior projects and literature were refined to reflect the insights gained during the project. These can now be used to design SME learning programmes. The digital literacy matrix can be used to assist selection of participants to both action learning programmes and virtual action learning programmes, taking into account the dimensions of structure and digital literacy. For those in the low structure / high literacy quadrant, benefits of the ENSeL virtual action learning programme were described as follows, and appropriate use of this model should bring similar benefits to many other SMEs. 
'The ENSEL Programme enabled me to gain greater awareness of my personal limitations - I have since promoted my more able staff and am learning to tolerate less perfectionist standards which are really quiteadequate for the job. This was important and is helping me to trust my staff more'

'I have a much clearer understanding of what I can delegate and more importantly, the tasks I must not delegate, such as leadership and communicating my vision to the staff'.

'I can now articulate the values of my company and communicate my passion for our products and our people'.

'I have been trying to decide whether I should offer a broad range of services or just specialise in a few, and I have recently tailored an offering for a specific customer, with the help of the learning group. I am also encouraged to build better relationships with my existing customers.'

'All the people in our learning set faced some very similar challenges. We were concerned about how we could grow the business, but still preserve the special nature of our products and people. I now feel more confident about my ability to do this.'

'Even though the project has finished, our group still meet and communicate virtually. There is a real comfort in knowing other people facing the same sort of problems and working it through together.'

This study has also indicated several challenges for future research and important practical issues to address, such as the low level of digital literacy in the SMEs involved in this programme. Despite the relatively small number of participants in the ENSEL trial programmes, the findings can be seen as making a significant contribution to this field of research.

Acknowledgements. We would like to thank the ENSeL project partners; IBM, Grenoble Ecole de Management (GEM), SAGO spa, Lancaster University, Catholic University of Louvain, Karolinska Insitutet, E.M.Lyon, University of Liege, Goteborgs Universitet, Learning Lab Denmark, Inspire Research Ltd.

\section{References}

1. Alexander, G. (2006) SME Learning Needs, Unpublished MBA Dissertation, Henley Management College, UK.

2. Attwell, G. (2003). Report on Brussels Seminar: Exploring Models and Partnerships for Elearning in SMEs. Developing New Pedagogies and Elearning in SMEs. Report on a seminar on Exploring models and partnerships for elearning in SMEs, held in Stirling, Scotland and Brussels, Belgium, in November 2002 and February 2003.

3. Birchall, D., Hender, J. and Alexander, G (2004), Virtual Action Learning for SMEs - a review of experiences gained through the ESeN Project. Henley Management College

4. Blackburn, R. and Hankinson, A. (1989), Training in the Smaller Business: Investment or Expense? Industrial and Commercial Training, Vol. 21, No. 2.

5. Bolden, R. (2001), Leadership Development in Small and Medium Sized Enterprises: Final Report, Centre for Leadership Studies, University of Exeter. 
6. Bray, J. (2002), Virtual Tutoring in Hospitality: A 'Learnt System' of Professional Practice. International Journal of Contemporary Hospitality Management, Vol. 14, No. 1, pp. 21.

7. Cranfield University (2005). Six classic barriers to growth and how to overcome them. Press release, Cranfield University School of Management

8. Eraut, M. (2000). Non-formal learning, implicit learning and tacit knowledge in professional work. In Coffiel, Frank The Necessity of Informal Learning publ Bristol, Policy Press

9. Esnault, L. and Ponti, M. (2004). The theory and practice of computer supported collaborative learning. EQUEL project position paper

10. Guile, D. (1998). Information and Communication Technology and Education. London, Institute of Education, University of London.

11. Hilton, M. and Smith, D. (2001) Professional education and training for sustainable development in SMEs. European Foundation.

12. Hodgson, V., \& Watland, P. (2004). Researching networked management learning. Management Learning. 35 (2): 99-116.

13. Inglis, S. (1994), Making the Most of Action Learning, Hampshire: Gower.

14. Ingram, H., Biermann, K., Cannon, J., Neil, J. and Waddle, C. (2000), Internalizing Action Learning: A Company Perspective, International Journal of Hospitality Management, Vol. 12, No. 2.

15. Kirby, D. (1990). Management Education and small business development: an exploratory study of small firms in the UK. Journal of Small Business Management, Vol.28 Issue 4, p78

16. Knowles, M. S. (1970) The Modern Practice of Adult Education. Andragogy versus pedagogy, Englewood Cliffs: Prentice Hall/Cambridge.

17. Knowles, M.S. (1984), The Adult Learner: A Neglected Species, Houston: Gulf Publishing.

18. Learning and Skills Development Agency (LSDA), 2002. Working towards skills: Perspectives on workforce development in SMEs. Research report

19. Lave J., \& Wenger, E. (1991). Situated Learning: Legitimate Peripheral Participation. Cambridge University Press: New York, NY.

20. Observatory of European SMEs (2002). SMEs in Focus. Main Results from the 2002 Observatory of European SMEs. (KPMG/ENSR). Enterprise DirectorateGeneral of the European Commission. Office for Official Publications of the European Communities, Luxembourg.

21. Observatory of European SME 2003, No.1 'Competence Development in SMEs'. Enterprise Directorate-General of the European Commission. Office for Official Publications of the European Communities, Luxembourg

22. Pedler, M., Brook, C. and Burgoyne, J. (2003), "Motion Pictures", People Management, April, pp. 41-44. 23. Ponti, M. (2004). Towards a conceptual framework for analysing the sustainability of elearning networks in SMEs. Positioning paper for the ENSeL project

24. Revans, R.W. (1980) Action Learning. Blond and Briggs, London

25. Small Business Service (2003a) VAT Registrations and Deregistrations, 19942002. www.sbs.gov.uk/statistics.

26. Small Business Service (2004) SME statistics UK 2004: SBS 2004. www.sbs.gov.uk/statistics. 
27. Stanworth, J., Purdy, D. and Kirby, D.A. (1992), The Management of Success in "Growth Corridor" Small Firms, Small Business Research Trust Monograph.

28. Stewart and Alexander (2006) - Engaging SMEs in an E-Learning Trial Paper presented at the Networked Learning Conference, Lancaster University, April 2006.

29. Unisys (2005). Final Report: E-Learning in continuing vocational training, particularly at the workplace, with emphasis on small and medium enterprises. Directorate General for Education and Culture EAC-REP-003

30. Van Winkelen, C. (2003), Inter-organisational Communities of Practice'. Working Paper, Henley Management College

31. Williams, S. (2003). The Learning Manager: Knowledge, action and social practice. Working Paper, Henley Management College

32. Wilmott, H. (1994) Critical management learning in J. Burgoyne \& M. Reynolds (Eds) Management Learning: integrating perspectives in theory and practice (London, Sage), 161-176

\section{Appendix: A}

Peter's Challenge (names have been changed):

One of my business challenges is Leadership, particularly leading the company through a period of change. During my short corporate working life (redundant twice, sacked once) I never got to a position of leadership. I have no leadership training, no role models, no mentors (the attraction of the course?). As the business has grown from wife, husband plus one (now 10 of us this week) then my role has become one of leader. The more the company grows and changes the more this will become my role. So what skills do I need? How do I get them - are they inherent or can they be learnt? What are the leadership issues? Should I bring someone else in to lead? How do I communicate my deep vision for the business? Of course I have a view on each of these questions but how do others deal with them and are there examples of good leadership from which we can all learn? So this is the second area of focus for The X Company.

Feedback from other set members:

\begin{tabular}{|l|l|l|}
\hline ISSUE & FROM & \multicolumn{1}{|c|}{ FEEDBACK } \\
\hline Leadership & Karen & $\begin{array}{l}\text { I would recommend paying for and attending a } \\
\text { training programme specifically for } \\
\text { leadership development and self-awareness of } \\
\text { leadership strengths/areas for development. } \\
\text { Mentoring also good. Would suggest Peter looks to } \\
\text { his own skills prior to bringing in another person to } \\
\text { lead. }\end{array}$ \\
\hline & $\begin{array}{l}\text { You've probably got a lot of skills already but } \\
\text { just don't know it. Is there anyone you know who } \\
\text { could mentor you? What about a non-executive } \\
\text { director to help you work through many of the }\end{array}$ \\
\hline
\end{tabular}




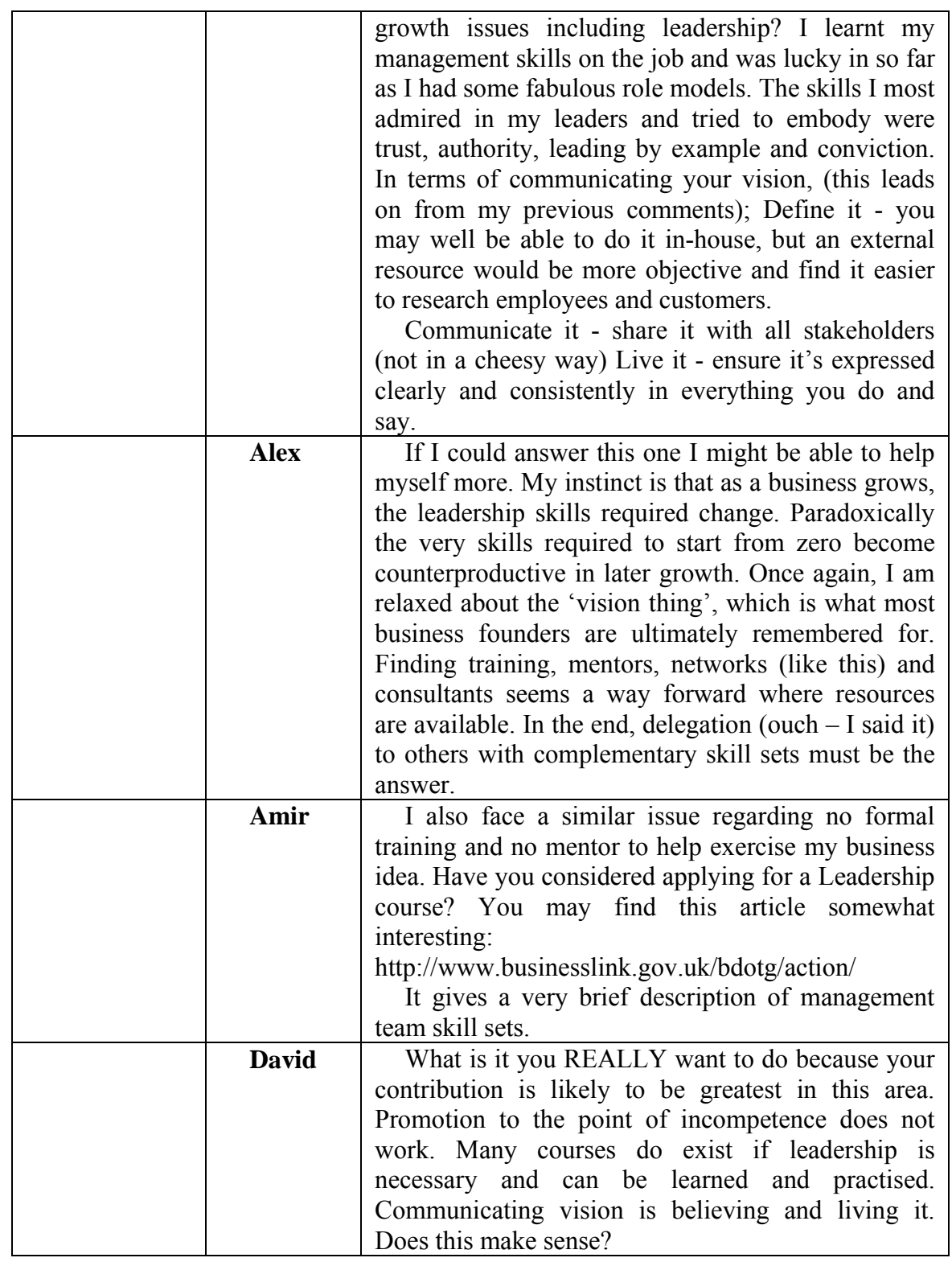

